\title{
Sarkozy: Et stærkt Frankrig i et effektivt EU
}

\section{Ulla Holm}

\section{Den 16. maj 2007 blev den tidligere indenrigs- minister, gaullisten Nicolas Sarkozy indsat i præsidentembedet}

De europæiske statsledere havde med spænding ventet på udfaldet af det franske præsidentvalg. Ikke mindre spændt ventede den franske befolkning på valgresultatet.

Statslederne håbede på, at en ny fransk præsident ville kunne sætte gang i diskussionen om en ny europæisk traktat efter det franske nej ved folkeafstemningen om den europæiske forfatningstraktat den 29. maj 2005. De franske vælgere ventede på, at 'noget nyt' ville ske på det indenrigspolitiske plan efter tolv år med gaullisten Jacques Chirac ved det præsidentielle ror.

Frankrig befandt sig under Chiracperioden $(1995-2007)$ i en politisk identitetskrise, hvor mismodet havde været fremherskende. Økonomisk liberalisering og en vis forringelse af hidtidige sociale rettigheder karakteriserede både de borgerliges og socialisternes politik. Samtidig havde begge fløje konstant understreget, at de var tilhængere af en stærk stat, der skulle intervenere i $\varnothing$ konomien og sikre social retfærdighed. Når dette ikke kunne lade sig gøre, var det ifølge mange franske politikere, fordi EU ikke ville det samme som de franske regeringer og præsidenten. Dermed postuleredes det, at de fleste af de økonomiske og sociale dårligdomme kom udefra.

Den Femte Republiks sjette præsident, Nicolas Sarkozy, har meldt sig parat til at smøge ærmerne op for at 'redde' Frankrig.

\section{Brud med fortidens synder}

Sarkozy blev præsident, fordi han fremstod som den, der bedst kunne gøre op med det politiske mismod samt bringe orden i det franske politiske hus. Orden, autoritet, hierarki, 
fortjeneste og arbejde. Det var disse værdier, der gik som en rød tråd gennem alle Sarkozys valgtaler. Ifølge Sarkozy var disse værdier blevet trådt under fode af Maj 68's anarkistiske oprørere. Sarkozy affyrede et værdimæssigt skud mod tidligere tiders 'slaphed' og ville et 'brud' med fortidens synder.

Det viste sig dog ret hurtigt, at ordet 'brud' var for hård en politisk kost i en valgkamp i Frankrig, som næst efter de skandinaviske lande har det bedste sociale system i Europa. Et brud med den franske sociale model ville betyde, at Sarkozy ville miste stemmer til den socialistiske præsidentkandidat Ségolène Royal, som centrerede sin valgkamp om nødvendigheden af bedre sociale ydelser, mere beskyttelse af de svage samt langsom tilpasning til den økonomiske globalisering.

Fra slutningen af 2006 begyndte gaullisten Sarkozy derfor at tale om 'et stille brud'. Det var en underforstået reference til afdøde præsident Mitterrands valgslogan i 1988: 'Frankrig: den stille kraft.' Sarkozys reference til Mitterrand tog fart, efter han blev udnævnt som gaullistpartiet UMP's (Union pour un movement populaire) præsidentkandidat den 14. januar 2007. Referencen signalerede, at Sarkozy ville være præsident for både højre- og venstrefløj. Det medførte en stadig større betoning af nødvendigheden af at gøre noget ved fattigdommen.

I slutningen af januar 2007 udtal- te Sarkozy, at han 'havde ændret sig'. Han forstod nu, hvor stor betydning den nationale identitet havde, og hvor alvorlige konsekvenser globaliseringen havde for den franske arbejder. Dermed var han ovre i en ny fase af sin præsidentielle udvikling. Sarkozy ville nu 'åbenhed og forsoning'. Han strakte hånden ud til hele befolkningen, ligesom de Gaulle havde gjort det i 1962 ved indførelsen af direkte valg til præsidentembedet. Dengang legitimerede de Gaulle det direkte valg med, at 'et præsidentvalg er et møde med folket'.

\section{Mere gaullist end de Gaulle}

Gaullisten Sarkozys selviscenesættelse som statsmand havde i første instans anvendt den socialistiske Mitterrand-figur - ikke mindst for at tage vinden ud af de socialistiske sejl. Mellem første og anden runde af præsidentvalget rettede han logisk nok blikket mod de Gaulle som den store statsmand. Sarkozy tog derfor af sted til et spirituelt møde med de Gaulle ved dennes grav i Colombey-les-Deux-Églises.

Dette møde signalerede, at han ikke var bruddets mand, men kontinuitetens og almenvellets beskytter. Ved graven udtalte han til vrimlen af journalister: "General de Gaulle inkarnerede lidenskaben for almenvellet og derfor for selvforglemmelsen. Colombey er beviset på en periode, hvor Frankrig ikke tvivlede på 
sig selv, og general de Gaulle er håbets symbol. Da alt var tabt, fik de Gaulle franskmændene til at håbe igen. Jeg holder af Frankrig, og jeg vil indgive franskmændene håb”.

Kvintessensen af gaullismen er "en vis ide om Frankrig og en vis ide om magten'. De Gaulle blev præsident for at redde Frankrig ud af fjerde republikkens parlamentariske kaos og dens afmagt over for Algeriet-krigen. Det gjorde han på basis af en kombination af politisk pragmatisme og af indførelse af femte republikken, som gav enorme magtbeføjelser til præsidenten.

En stærk præsident - højt hævet over 'partifnidder' - skulle garantere, at præsidenten handlede i almenvellets navn og, at Frankrig igen kunne komme til at spille en rolle i Europa og globalt. Det er denne repræsentation af den stærke præsidents rolle i genrejsningen af Frankrig - til almenvellets bedste - som Sarkozy henviser til i sin tale.

Sarkozy vil være mere gaullistisk end de Gaulle var. Det mener i hvert tilfælde flere franske forskere og kommentatorer. Denne vurdering skyldes, at Sarkozy ofte har erklæret, at 'republikkens præsident skal regere, fordi franskmændene forventer endnu mere engagement og energi end tidligere'. En sådan udtalelse involverer, at statsministeren blot skal eksekvere præsidentens ordrer i stedet for 'at styre', som der står i forfatningen.

Hertil kommer, at Sarkozy har meddelt, at han vil evaluere sine ministres arbejde hvert år samt, at han vil gøre rede for sin politik i parlamentet en gang om året, hvad der kræver en forfatningsændring. Styrke, styring, orden og autoritet skal udgå fra præsidenten for at sikre, at nationen igen bliver en enhed. En stærk stat, en stærk præsident og en stærk nation bliver således tre sider af samme sag: at genrejse Frankrig.

Resultatet af anden runde af nationalforsamlingsvalget (parlamentsvalg), gav en så komfortabel sejr til Sarkozy og de borgerlige partier, at de uden problemer kan gennemføre de lovede reformer, der ifølge Sarkozy er nødvendige for at 'redde' Frankrig ud af stilstanden.

\section{Sociale reformer}

Sarkozy har givet sig selv 100 dage til at bevise, at han er reformernes og handlingens mand. Det første, han gjorde, var at danne en regering, hvis sammensætning af venstre-højre ministre signalerede vilje til åbenhed og hensyntagen til fattigdomsproblemerne.

Den socialt bevidste gaullist François Fillon, tidligere uddannelses- og social minister, blev udpeget som premierminister. På den vigtige post som justitsminister udpegede Sarkozy en kvinde, andengenerationsindvandreren Rachida Dati, som siden 2002 havde været Sarkozys rådgiver i kriminalitetsbekæmpelse. Han udnævnte Martin Hirsch, Abbé 
Pierres efterfølger som formand for hjælpeorganisationen Emmaüs Fran$c e$, til den nyoprettede post som højkommissær for 'aktiv solidaritet mod fattigdom'. Regeringen består således af et udvalg af socialt indstillede repræsentanter for de penible områder, som Sarkozys økonomiske - og sociale love vil fokusere på.

Valget af ovenstående ministre signaler både en hård intern sikkerhedspolitik over for 'uromagere' i forstæderne og en social liberal samfundsindstilling.

Venstrefløjen har skældt Sarkozy ud for at være 'ultraliberalist' og for at være en 'amerikaner med et fransk pas'; men det er en sandhed med modifikationer. Da Sarkozy var finansminister blev erhvervsskatter og udgifter til sociale ydelser ikke reduceret. Han kom også virksomhedsgiganten inden for togproduktion og elektronik, Alsthom, til statslig undsætning, da virksomheden var i økonomiske problemer.

Ikke på noget tidspunkt i fransk efterkrigshistorie har der været regeringer, der har været fortalere for en engelsk/amerikansk liberal økonomisk politik - og det til trods for at der er sket en liberalisering og privatisering i forbindelse med det indre markeds indførelse. Den generelle franske modvilje mod økonomisk liberalisme skyldes, at højrefløjen har udviklet sig i skyggen af katolicismens sociale indstilling og venstrefløjen har været og er stadig tilknyttet marxistisk tankegods. Den franske velfærdsstat - dvs. den franske sociale model er i lige så høj kurs i Frankrig, som den danske sociale model er det i Danmark. Der er derfor grænser for, hvor liberalistisk Sarkozy kan være.

Den første sag Sarkozy formentligt vil tage fat på, bliver indførelse af en lovbefalet minimumservice i den offentlige transport i tilfælde af strejker. Sarkozy har meddelt, at lovforslaget først skal diskuteres med fagforbundene. Der skal dermed forhandles. Spørgsmålet er, hvor lang tid Sarkozy vil vente på fagforbundenes mulige kompromisforslag.

\section{Arbejdsmarkedet}

Det stive arbejdsmarkedssystem skal revolutioneres. Det skal være lettere at afskedige folk; men samtidig skal arbejdsløshedsstøtten også være højere. Universiteterne skal åbnes mod virksomhederne og gøres delvist uafhængige af staten. De favorable pensionssystemer for offentligt ansatte skal 'slankes'. Den offentlige sektor skal på sigt reduceres, idet Sarkozy har foreslået, at kun en stilling i det offentlige skal genbesættes, hver gang to ansatte går på pension.

Franskmændene skal arbejde mere og længere. En reform af 35 timers-ugen er således top prioritet. Den skal ikke afskaffes, men omgås ved at afskaffe skat på overarbejde. Hertil kommer yderligere, at skatteloftet skal sænkes fra $60 \%$ til $50 \%$. Arveafgiften skal reduceres - faktisk 
helt afskaffes for $90 \%$ af befolkningen.

Hvad angår sikkerhedsproblematikken, som var et af de store temaer i valgkampen, har Sarkozy bebudet, at den kriminelle lavalder vil blive sænket fra 18 år til 16 år for de unge, som har begået flere kriminelle handlinger. Da immigration betragtes som et sikkerhedsproblem, har Sarkozy også meddelt, at reglerne for familiesammenføring skal strammes. Eksempelvis skal en nordafrikaner, som ønsker at blive familiesammenført, på forhånd kunne bevise, at hun/han kan fransk.

De sociale og økonomiske reformer, som har været på dagsorden under hele Chirac-perioden (1995 2007), har konstant stødt imod massive protester. Store strejker i den offentlige sektor har gang på gang stoppet reformerne på halvvejen. Testen på Sarkozys handlekraft, men også evne til at indgå kompromisser, vil komme på en stor prøve i løbet af sommeren 2007, hvor lovforslagene stilles og måske vedtages.

\section{Fra mini til forenklet traktat}

"Nu kan en minitraktat ligge klar ved udgangen af 2007". Det var med disse ord, Anders Fogh Rasmussen ønskede Sarkozy tillykke med sejren. Der er ingen tvivl om, at Fogh Rasmussen er lettet over, at det blev den borgerlige Sarkozy og ikke socialisten Ségolène Royal, der blev præsident. Royal ville sende en ny trak- tat til folkeafstemning, hvorimod Sarkozy vil ratificere en ny traktat i den franske Nationalforsamling for at undgå endnu et muligt nej til en ny europæisk traktat.

Det passer godt i det danske, men også i det engelske politiske kram, at Sarkozy er fortaler for en minitraktat, eller rettere en forenklet traktat, som han i foråret 2007 valgte at kalde sit forslag. Danmark, Storbritannien og Frankrig er alle enige om, at der skal så lidt med af den afdøde europæiske forfatningstraktat som muligt i en ny traktat. Men de 18 lande, som allerede enten har ratificeret eller sagt ja ved folkeafstemning til den afdøde forfatningstraktat har ikke været begejstrede for en forenklet traktat.

Den selv samme dag, Sarkozy blev indsat som præsident, tog han flyet til Berlin for at mødes med kansler Angela Merkel, leder af det tyske EU-formandskab. I Berlin forsikrede Sarkozy den tyske kansler om fransk vilje til at tage europæiske initiativer. Sarkozy meddelte, at han ville hjælpe Merkel med at finde en løsning på EU's institutionelle krise. En succes for det tyske formandskab, ville også være en succes for Frankrig.

EU skal være effektivt, lyder det fra den nye præsident. Sådan har det lydt både fra Mitterrand og Chirac. EU skal være effektivt for at kunne handle over for de europæiske naboer og på globalt plan. Ingen må snige sig ind ad EU-døren, før EU er så handlekraftigt ind- 
adtil, at det kan 'styre' de nye, der banker på døren.

Effektivitet involverer ifølge Sarkozy først og fremmest institutionel effektivitet. Derfor slog han på tromme i 2006 for en minitraktat. I 2007 ændrede han dette begreb til en 'forenklet traktat'. Det er ikke en tilfældig ændring. En forenklet traktat kan defineres på mange forskellige måder. Den åbner for, at der kan tilføjes nye politikområder.

Sarkozy har da også i flere taler åbnet for, at der kan tilføjes en social protokol til traktaten. Det var oprindeligt Royals forslag; men Sarkozy 'stjal' det for at vise, at også han var klar over, at en af de vigtigste årsager til det franske nej til forfatningstraktaten var, at en stor del af befolkningen ikke mente, at den europæiske forfatningstraktat sikrede tilstrækkelig social beskyttelse imod globaliseringen.

Sarkozy har åbnet døren op for forståelse af den franske befolknings angst for fremtidens EU. Han har ligeledes forsøgt at tage højde for de atten lande, som enten har ratificeret eller har stemt for den europæiske forfatningstraktat. Det har han gjort ved at tale om to etaper i udarbejdelse af en ny traktat, som $i k k e$ skal være en forfatning.

Den første etape skal være fuldført i slutningen af 2007, hvor den forenklede traktat skal være udarbejdet. Dernæst skal den ratificeres under det franske formandskab i anden halvdel af 2008. Anden etape skal starte i 2009, hvor indholdet og formålet med EU skal diskuteres på enten en regeringskonference eller $i$ et konvent. Sarkozy stiler åbenbart mod en 'Paris-traktat', som kan kaste glans over Frankrig og dermed få Frankrig til på ny at fremstå som 'founding father' af EU.

De institutionelle forslag er overhovedet ikke nye. Langt størsteparten blev udtænkt af Chirac og den socialdemokratiske tyske kansler Schröder i november 2002, hvor de to herrer fremlagde et fælles forslag til Det Europæiske Konvent, der var i færd med at udarbejde forslaget til en europæisk forfatningstraktat. De tysk-franske forslag svarer også nogenlunde til den forsmåede forfatningstraktats institutionelle forslag.

\section{Den fransk-tyske akse}

Kansler Angela Merkel har reageret positivt over for forslaget. Det gør hun over for alle forslag, fordi hun skal strikke de forskellige forslag sammen inden topmødet den 21.22. juni 2007, hvor Portugal overtager EU-formandskabet. Men den symbolik, der ligger i, at Sarkozy straks tog til Berlin, skal ikke undervurderes.

Der har været talrige gisninger, om Sarkozy ville fortsætte det tætte samarbejde med Tyskland, når han nu er så begejstret for Tony Blairs politik. På forsvarsområdet kan Frankrig og Storbritannien arbejde sammen. Men der er ikke fælles 
fodslag, hvad angår politikken over for udvidelser, forholdet til Tyrkiet $o g$ til euroen (se neden for).

Grunden til de europæiske statslederes usikkerhed om indholdet af Sarkozys europavision skyldes bl.a., at Sarkozy i et interview i 2006 havde erklæret, at den fransk-tyske akse - ligegyldigt hvor nødvendig den end var - ikke var stærk nok til at relancere den europæiske vision. Derfor foreslog han, at aksen blev udvidet med Storbritannien, Italien, Benelux, Spanien og Polen, fordi 'de store lande bør sætte et eksempel for andre lande'.

Nogle dage efter denne udtalelse erklærede han, at hans forslag var affødt af de nye EU-landes modvilje mod det fransk-tyske direktorat. Denne korrektion mindskede unægteligt ikke de små landes mistænksomhed over for mulige franske europæiske storhedsdrømme. Men talen om at de store lande skal styre de små - en tale som også Chirac førte - er forsvundet fra Sarkozys europavision. I stedet har han gentagne gange erklæret, at det skal være lettere at indgå i 'styrkede samarbejder', hvad den forenklede traktat også lægger op til.

Det er heller ikke en ny ide. Allerede Amsterdam-traktaten fra 1997 havde gjort det lettere at etablerede styrket samarbejde. Dette samarbejde fik forskellige navne. Chirac forslog således en 'pionergruppe' som svar på den daværende tyske udenrigsminister Joschka Fischers forslag om et Kerneeuropa - et gravitetscenter. Når Sarkozy taler om nødvendigheden af, at nogen lande bør kunne gå videre i integrationen, selv om andre lande ikke er parate hertil, ekkoer han Chiracs tale i den tyske rigsdag i juni 2000:

"De lande, der frivilligt og på særlige områder ønsker at gå længere med integrationen - man kunne kalde dem en pionergruppe - skal kunne gøre det uden at blive holdt tilbage af dem, der er i deres gode ret til ikke at gå så hurtigt frem”.

\section{Sikkerhedsschengen}

Det styrkede samarbejde, som Sarkozy især er interesseret $i$ at få iværksat, drejer sig om EU's indre sikkerhed. Han har foreslået et 'Sikkerhedsschengen', som skal bekæmpe terrorisme, illegal immigration og kriminalitet. Til den ende har han foreslået oprettelse af et europæisk interventionskorps, kaldet de grønne hjelme

Det er en Sarkozy-opfindelse. Den afspejler hans indenrigspolitiske trusselsopfattelse og midlerne til at bekæmpe truslerne. Den anskuer EU, som en forlængelse af Frankrig. Frankrigs trusselsopfattelse er i Sarkozys vision den samme som EU's og de andre europæiske staters. Hans grønne hjelme har få chancer for at få opbakning på EU-niveau, da EU-medlemsstaterne har forskellig trusselsopfattelse.

Sarkozy opererer foreløbigt med 
tæt samarbejde med Tyskland og styrket samarbejde inden for specifikke områder med andre EU-lande. Det er gammel vin på gamle flasker. Denne franske europavision har været tydelig siden Maastricht-traktaten blev vedtaget ved folkeafstemning i Frankrig 1992. Den baner sig stadig mere vej pga. de store udvidelser i 2004, der vanskeliggører fælles politikker på alle områder.

Under valgkampen refererede Sarkozy ofte til Mitterrand og mindre hyppigt til de Gaulle. Han takkede høfligt Chirac for hans udenrigsog europapolitik. Han burde have takket Chirac mere, fordi han genbruger Chiracs europavision på et vigtigt punkt: Han fortsætter Chiracs vision om den fransk-tyske motor som grundpillen i EU-integrationen, og denne motor kobles sammen med begrebet 'styrket samarbejde', der arbejder sammen om forskellige tematikker.

Den borgerlige Sarkozy er imidlertid mere et barn af Mitterrand end af de Gaulle og Chirac. Det er han, fordi han fortsætter Mitterrands vision om et Europa, der skal kunne alt det, som Frankrig ikke længere kan.

Imidlertid står Sarkozy i en anden indenrigspolitisk situation end Mitterrand. Han står med et stort nej til den europæiske forfatningstraktat. Han er derfor i det dilemma, at han skal forene både ja- og nej-stemmerne til forfatningstraktaten. Han er foreløbigt kommet ud af dilemmaet med forslaget om en forenklet traktat.

Men dilemmaet om forholdet mellem Frankrig og EU står stadig tilbage.

\section{Frankrig er tilbage i Europa}

Sarkozy ville med sit hurtige besøg i Berlin vise, at der stod diplomatisk handling bag hans sejrstale, hvor han udtalte at, 'nu var Frankrig tilbage i Europa'. Spørgsmålet er, hvilket Europa han taler om.

Sarkozys udtalelse om, at 'en europæisk ambition er en forlængelse af den franske ambition', kan nok få en og anden statsmand/kvinde til at blive bekymret for, om Frankrig vil følge nationale særinteresser. Men alle EU-medlemslandene forfølger særinteresser. Alle har de en særlig vision om sig selv, som de prøver at få igennem på EU-niveau. Hvis ikke vigtige dele af en specifik europavision bliver tilgodeset på EU-niveau, vil den nationale skepsis over for EU-integrationen vokse.

Grundpillerne i Sarkozys europavision er identiske med Mitterrands. EU skal være et klart defineret område med faste grænser. Det skal det være, for at EU kan handle. Lige fra starten af udvidelserne efter Murens fald har det lydt fra Paris, at der skal ske en institutionel uddybning før udvidelse. Det var Mitterrands budskab, og det er Sarkozys. Det skal være 'grænsernes Europa', som Sarkozy siger. 


\section{Tyrkiet}

Dette 'grænsernes Europa' gælder ikke indlemmelse af Kroatien i EU. Men det gælder absolut Tyrkiet. Ifølge Sarkozy bør forhandlingerne med Tyrkiet standses med det samme. I stedet skal Tyrkiet tilbydes et privilegeret partnerskab, hvad det tyske kristen-demokratiske parti CDU, som Merkel tilhører, også har foreslået.

Sarkozy har været ude med utallige begrundelser for at holde Tyrkiet ude. Den ene ligger i forlængelse af visionen om det stærke politiske EU, idet Sarkozy har ytret, at "hvis Tyrkiet kommer med, så er det politiske EU en saga blot". Det andet argument ligger tæt op af det yderste højres argument mod tyrkisk EUmedlemskab. Sarkozy lancerede den 5. oktober 2006 et anti-islam argument: "Vi har et problem med muslimers integration, hvad der sætter spørgsmålstegn ved islams position i Europa. Hvis man ikke vil indrømme, at det er et problem, så ser man ikke realiteterne i øjnene. Hvis 100 millioner tyrkere komme ind i Europa, hvad kan der så ikke ske?”

Ligegyldigt hvilket argument Sarkozy anvender i modstanden mod tyrkisk medlemskab, er han på linje med størsteparten af den franske befolkning, som er en af de europæiske befolkninger, der er mest imod tyrkisk medlemskab.

Men det er politisk vanskeligt at afbryde forhandlingerne. Bruxelles har meldt klart ud, at forhandlingerne skal fortsætte. Sarkozy skal derfor finde en vej ud af det dilemma, han står i. Det er han ved at gøre. Først og fremmest udpegede han en udenrigs- og europaminister, den berømte Bernard Kouchner, som går ind for tyrkisk medlemskab. For det andet meddelte Sarkozy i slutningen af maj 2007, at spørgsmålet om tyrkisk medlemskab først skal til diskussion, når den forenklede traktat er blevet ratificeret.

Det sker under det franske formandskab i efteråret 2008! I mellemtiden vil Sarkozy arbejde for, hvad han kalder 'en middelhavsunion'. Denne union skal ifølge Sarkozy omfatte det sydlige arabiske Middelhav samt Tyrkiet. Unionen skal være en bindestreg mellem EU og Afrika.

Der er mindst to problemer med det begreb. For det første forklarer Sarkozy ikke, hvordan en sådan union skal tænkes sammen med EU's Naboskabspolitik og Barcelona-processen. For det andet vil Tyrkiet overhovedet ikke placeres i en organisation, som bringer det på politisk linje med arabiske lande.

Sarkozys unionside er logisk set ud fra begrebet om det stærke EU, som Mitterrand var fortaler for. Men ideen lider givetvis lige så krank en skæbne som Mitterrands ide i 1989 om en konføderation for østlandene. Det ville østlandene ikke være med til. De ville ind i EU-varmen. Det samme vil Tyrkiet. Problemet bliver derfor for Sarkozy, hvordan 
han skal forklare franskmændene, hvorfor Tyrkiet måske kommer lidt længere ind i EU de følgende år.

Men måske klarer Tyrkiet selv problemet for ham ved at blive kastet ud i så store interne kriser, at EU kan skubbe medlemskabet stadig længere ud i fremtiden.

\section{Til kamp mod globaliseringen}

Årsagerne til nej'et til den europæiske forfatningstraktat prægede al debat om de interne forhold $i$ Frankrig og præsidentkandidaternes europavision.

I en eurobarometer opinionsundersøgelse, der blev foretaget lige efter nej'et, var de fem vigtigste årsager til nej'et ud af 20:

1) at forfatningstraktaten ville få negativ indflydelse på beskæftigelsen; 2) at den ville fremskynde udflytning af virksomheder og dermed forårsage yderligere arbejdsløshed; 3) at traktaten var for økonomisk liberal;

4) at man var i opposition til præsidenten/regeringen/visse partier: og

5) at det sociale aspekt ikke var tilstrækkeligt sikret.

En fransk forskningsrapport fra 2007 bekræftede den franske uvilje mod globalisering. Rapporten havde undersøgt Tysklands, Spaniens, Polens, Storbritanniens, Sveriges og Frankrigs opfattelse af globalisering. Af de lande var Frankrig klart det land, hvor der var mest bekymring.
Internt vil Sarkozy slanke staten samt forsøge at indføre den danske 'flex-security-model' på arbejdsmarkedet. Eksternt - i EU - vil han beskytte de franske borgere mod 'globaliseringens trojanske hest'. Det indre marked skal have forrang.

Ifølge Sarkozy må 'de kapitalistiske globale rovdyr' ikke dumpe deres varer inden for EU. Derfor skal EU beskyttes imod især asiatisk unfair industriel konkurrence og mod amerikansk konkurrence inden for landbrugsproduktion. EU skal føre en samlet industripolitik. På fransk vil det sige, at EU skal redde de skrantende virksomheder, der enten ikke kan klare sig i globaliseringens EU eller flytter ud af EU for at få billig arbejdskraft.

Det lyder ikke som økonomisk liberalisme. Det lyder snarere som gammelkendt fransk protektionisme, der ikke længere kan gennemføres på fransk nationalt niveau, men i stedet skal føres op på EU-niveau, hvor kampen mod globaliseringen skal føres. Det er en forlængelse af Mitterrands EU-vision om et stærkt EU, det skal være en forlængelse af den franske stat. EU skal være en 'mangedobler af magt' ifølge Sarkozy. Det er også en vending, der hyppigt blev brugt af Mitterrand og Chirac.

\section{Landbruget}

Kampen mod 'de globale rovdyr' skal ikke alene føres på EU-niveau. 
EU skal sikre, at denne kamp også føres i WTO. Det gælder især spørgsmålet om landbrugspolitik. Sarkozy har udtalt sig i kryptiske vendinger om det franske landbrugs fremtid. På den ene side udtaler han, at han vil bakke hundrede procent op om EU's landbrugsstøtte. På den anden side har han advaret mod, at hjælpen til landbruget bliver uforholdsmæssig stor i forhold til produktionsværdien.

Det er under alle omstændigheder Sarkozy, som de andre europæiske statsledere skal lave kompromiser med om landbrugsstøtten, der skal revideres i 2013. Sarkozy er foreløbigt præsident indtil 2012. Men ligegyldigt hvor kryptisk han udtaler sig, bliver der hårde kampe både $\mathrm{i}$ WTO og i EU om landbrugsstøtten, fordi Frankrig dels anser landbruget som en fransk identitetskabende faktor dels som et bevis på, at den fransk-tyske motor fungerer. Landbrugsstøtten byggede oprindeligt på, at Tyskland gav penge til fransk landbrug mod at tysk industri fik adgang til et frit marked.

Sarkozys kritik af manglen på politisk styring af Den Europæiske Centralbank er ikke nogen ny fransk tale. Hans krav om etablering af en økonomisk regering, der skal fastlægge de generelle retningslinjer for fællesskabets penge- og valutakurspolitik og for medlemslandenes finanspolitik, er ej heller et nyt krav. Alle disse krav blev også fremført af Mitterrand og Chirac. Sarkozy har desuden ytret sig i skarpe vendinger mod, hvad han mener, er en overvurdering af euroens værdi. Der er ikke noget, der tyder på, at disse krav bliver indfriet af EU.

Sarkozy havde ikke brugt mange ord på EU's sociale dimension før han blev præsidentkandidat. Men i løbet af foråret 2007 understregede han gentagne gange, at den Økonomiske og Monetære Union skal prioritere vækst og beskæftigelse. Den økonomisk-monetære politik skal humaniseres dvs. være socialt orienteret. Man kan derfor forestille sig, at Sarkozy er tilhænger af en social protokol til den forenklede traktat. En sådan protokol afspejler også Mitterrands ide om det sociale EU. Mitterrand fik i 1992 indføjet et socialt kapitel i Maastricht-traktaten.

EU skal beskytte sig mod udefra kommende varer, kapital og immigranter. En sådan vision er ikke antieuropæisk. Det er en fransk europæisk vision, som har dybe rødder i traditionen for fransk statsinterventionisme. Liberalisten Sarkozy har iført sig statstøjet. Spørgsmålet er, hvor lang tid den klædedragt kan bruges i samarbejdet med de andre europæiske statsledere. Hvis han må smide noget af tøjet, hvordan vil han så forklare den franske befolkning det?

Han har lovet, at der skal være overensstemmelse mellem ord og handling i modsætning til under Chirac. Det kan blive svært, fordi han kommer til at indgå kompromi- 
ser om, hvordan den økonomiske globalisering skal tackles på EU-niveau.

\section{Konklusion}

Under valgkampen blev Sarkozy af venstrefløjen kaldt atlantist, amerikaner med fransk pas, ultraliberalist og en barsk politiker. Kun den sidste betegnelse er korrekt. De to første betegnelser skyldes, at han besøgte George W. Bush i Washington i efteråret 2006. Han roste USA's samfundsmodel og kritiserede fransk arrogance i international politik. Det forårsagede at især venstrefløjen kastede sig over Sarkozy med anklager om, at han gik USA's ærinde i international politik.

Men grundstrukturen i fransk international politik har Sarkozy ikke ændret. Han har ofte henvist til de Gaulles ord om, at Frankrig og USA er allierede; men at Frankrig ikke automatisk er linet op bag amerikansk politik. Frankrig er ikke USA's vassal ifølge Sarkozy. Det samme sagde Chirac i forbindelse med det franske nej til tilslutning til krigen mod Irak. Man skal derfor ikke for- vente sig en betingelsesløs fransk tilslutning til amerikanske politikker. Det gælder i forhold til mulige fremtidige krige og til USA's landbrugspolitik i WTO-regi.

Den 'ultraliberale' Sarkozy har vist at være protektionist og socialt orienteret. Man kan gætte på alle mulige motiver for denne 'socialisering'; men man må tage ham på ordet og ikke på motivet, som ingen kender.

Ulla Holm er seniorforsker ved Dansk Institut for Internationale Studier (DIIS)

Artiklen er skrevet ferdig for det europaiske topmøde den 21.-22. juni

\section{Henvisninger:}

"Les fondements des politiques étrangères des pays Européens" (i) La Revue Internationale et Stratégique. Printemps 2006, no. 61. Paris.

Denis Bertrand, Alexandre Dézé et Jean-Louis Missika: Parler pour gagner. Sémiotique des discours de la campagne présidentielle de 2007. Sciences PO. Les Presses, Paris 2007.

Ulla Holm: Det gamle Frankrig i det nye Europa. DIIS, København 2006.

Nicolas Sarkozy: Ensemble X éditions, Paris 2007. 